\title{
HUBUNGAN AKTIFITAS FISIK DENGAN KEJADIAN OBESITAS SENTRAL PADA PASIEN POLIKLINIK JANTUNG DAN PENYAKIT DALAM
}

\author{
Gusnilawati, Septiyanti \\ Politeknik Kesehatan Kementerian Kesehatan Bengkulu, Jurusan Keperawatan, \\ Jalan Indragiri Nomor 03 Padang Harapan Kota Bengkulu \\ jmkbengkulu@gmail.com
}

\begin{abstract}
The purpose of this study to determine the relationship between physical activity and the incidence of central obesity and heart disease clinic patients in Hospital Dr. M. Yunus Bengkulu 2014. This research is a cross-sectional method and sampling conducted by accidental sampling technique. Independent variables (physical activity) and the dependent variable (central obesity). Total population of 5,021 people with a total study sample was 96 people. Results showed that there is a relationship between physical activity and the incidence of central obesity $(\mathrm{p}=0.000)$. It is expected that the clinic nurse to be able to improve the quality of health services, especially in patients who are at risk of central obesity and preventive improvement can be done by preventing the increase in central obesity by changing one's lifestyle by increasing activity on a regular basis.
\end{abstract}

Keywords : Central Obesity, Physical Activity .

\begin{abstract}
Abstrak: Penelitian ini bertujuan untuk mengetahui hubungan antara aktifitas fisik dengan kejadian obesitas sentral pada pasien poliklinik jantung dan penyakit dalam RSUD Dr. M. Yunus Bengkulu tahun 2014. Jenis penelitian ini adalah menggunakan metode CrossSectional dan sampling dilakukan dengan teknik accidental sampling. Variabel independent (aktifitas fisik) dan variabel dependent (obesitas sentral). Jumlah Populasi 5.021 orang dengan Jumlah sampel penelitian adalah 96 orang. Hasil Penelitian didapatkan bahwa ada hubungan antara aktifitas fisik dengan kejadian obesitas sentral $(\mathrm{p}=0,000)$. Diharapkan pada perawat poliklinik untuk dapat meningkatkan mutu pelayanan kesehatan khususnya pada penderita yang beresiko obesitas sentral dan dapat dilakukan peningkatan upaya prefentif dengan cara pencegahan peningkatan obesitas sentral dengan mengubah gaya hidup seseorang dengan meningkatkan aktifitas secara teratur.
\end{abstract}

Kata kunci : Obesitas Sentral, Aktifitas fisik

World Health Organization (WHO) memperkirakan, di dunia ada sekitar 400 juta orang dewasa obesitas sentral pada tahun 2005 dan diperkirakan $>700$ juta orang dewasa akan obesitas sentral pada tahun 2015. Menurut hasil Riset Kesehatan Dasar (Riskesdas) pada tahun 2007 di Indonesia menunjukan bahwa $18,8 \%$ orang dewasa obesitas sentral (Balitbangkes Depkes, 2008).

Obesitas sentral telah menjadi epidemi dengan memberikan kontribusi sebesar 35\% terhadap angka kesakitan dan memberikan kontribusi sebesar 15-20\% terhadap kematian. Menurut World Health Organization (WHO) 40-60\% penderita obesitas sentral adalah stimulator utama untuk terjadinya berbagai penyakit terutama sindroma metabolik, dia- betes mellitus tipe 2 dan hipertensi. Adanya peningkatan populasi obesitas di dunia akan meningkatkan penyakit kardiovaskuler dan merupakan penyebab kematian global terburuk pada abad ke-21 (Pusparini, 2007).

Review terhadap epidemi obesitas yang dilakukan oleh World Health Organization (WHO) memperlihatkan bahwa Prevalensi obesitas sentral pada laki-laki Amerika Serikat meningkat dari $37 \%$ menjadi $42,2 \%$ sedangkan pada perempuan meningkat dari 55,3\% menjadi $61,3 \%$ pada periode yang sama (Arundhana, 2012).

Berdasarkan distribusi lemak, obesitas dibagi menjadi dua kategori yakni: obsitas sentral dan obesitas umum. Untuk penduduk Asia, IMT-nya $>25 \mathrm{~kg} / \mathrm{m}^{2}$ atau lingkar perut $\geq$ 
$90 \mathrm{~cm}$ pada laki-laki dan $\geq 80 \mathrm{~cm}$ pada perempuan. Obesitas sentral dapat terjadi terutama akibat peningkatan asupan makanan dan penurunan aktititas fisik. Berbagai penelitian menemukan bahwa faktor resiko terjadinya obesitas sentral yang lain seperti konsumsi makanan yang tidak seimbang, konsumsi alkohol, riwayat merokok, kemajuan teknologi, status sosial ekonomi (Rosen, 2010).

Aktifitas berkontribusi terhadap penurunan berat badan dan melindungi massa tubuh. Hal ini membantu untuk mempertahankan laju metabolik yang ikut menurun ketika asupan energi berkurang. Aktifitas fisik berat juga menghasilkan peningkatan laju metabolik setelah berolahraga, sehingga meningkatkan pengeluaran energi. Pengeluaran energi yang tinggi dapat meningkatkan penggunaan lemak tubuh sabagai cadangan energi sehingga dapat mempertahankan berat tubuh yang normal (Mary, 2007).

Berdasarkan penelitian yang dilakukan oleh Himpunan Studi Obesitas Indonesia (HISOBI) ditemukan bahwa prevalensi obesitas sentral lebih tinggi daripada obesitas umum yaitu sebanyak $11,2 \%$ wanita dan $9,6 \%$ pria menderita obesitas umum. Sementara prevalensi yang lebih tinggi ditemukan pada kelompok obesitas sentral dimana pada pria $41,2 \%$ dan pada wanita 53,3\%. Kelompok dengan karakteristik obesitas sentral tertinggi di Indonesia berada dalam rentan umur 45-54 tahun sebanyak 27,4\% (Depkes RI, 2012).

Riskesdas 2007 juga melaporkan bahwa tiga prevalensi obesitas sentral tertinggi, yaitu Sulawesi Utara $31,5 \%$, Gorontalo $27 \%$ dan DKI Jakarta 27,9\%. Berdasarkan data-data diatas diperoleh bahwa prevelensi obesitas sentral semakin meningkat dari tahun ke tahun. Khususnya dinegara berkembang seperti Indonesia dan berkontribusi besar terhadap berbagai penyakit degeneratif maupun sindrom metabolik yang dapat meningkatkan resiko kematian (Elya, 2009).

Penelitian mengenai obesitas sentral secara internasional sudah cukup banyak dilakukan, akan tetapi di Indonesia sendiri masih cukup terbatas dan kebanyakan dilakukan pada kalangan ibu-ibu rumah tangga dan di daerah perkotaan. Penelitian mengenai obesitas sentral yang terjadi di Bengkulu sendiri belum pernah ada yang meneliti karena mayoritas masyarakat masih menganggap bahwa obesitas sentral adalah bukan suatu penyakit padahal Obesitas sentral berisiko kematian yang besar, seseorang dengan massa indeks massa tubuh yang normal tetapi dengan peningkatan lingkar perut, berisiko kematian $20 \%$ dengan penyerta penyakit degeneratif lainya seperti Hipertensi, lebih besar daripada seseorang dengan indeks massa tubuh dan lingkar perut yang normal (Pujiati, 2010).

Lokasi penelitian yang dipilih adalah poliklinik Jantung dan penyakit dalam di RSUD Dr. M.Yunus Bengkulu dengan pertimbangan bahwa RSUD Dr. M.Yunus merupakan tempat yang strategis dan sebagai pusat rujukan di kota Bengkulu sehingga memudahkan dalam pengambilan sampel. Berdasarkan survey awal yang peneliti lakukan pada tanggal 6 November 2013 dari pasien yang berobat di poliklinik jantung dan penyakit dalam RSUD Dr. M. Yunus Bengkulu yang terdiagnosa Hipertensi ada 15 orang dan 10 orang juga menderita obesitas sentral sedangkan untuk pasien yang terdiagnosa Diabetes Mellitus ada 14 orang dan 10 orang juga menderita obesitas sentral.

Penelitian ini bertujuan untuk mengetahui hubungan antara aktifitas fisik dengan kejadian obesitas sentral pada pasien poliklinik jantung dan penyakit dalam RSUD Dr. M. Yunus Bengkulu tahun 2014.

\section{BAHAN DAN CARA KERJA}

Jenis penelitian ini adalah Deskriptif Analitik dengan menggunakan rancangan penelitian Cross Sectional dimana peneliti mengukur variabel independen dan dependen secara bersamaan dan hasil yang diperoleh menggambarkan kondisi yang terjadi saat penelitian dilaksanakan. Populasi dalam penelitian ini adalah semua pasien rawat jalan berada di poliklinik jantung dan penyakit dalam Bengkulu Tahun 2014 yang berjumlah 5.021 orang. Sampel yang diambil dalam penelitian ini adalah sebagian pasien yang berkunjung di poliklinik jantung dan penyakit 
dalam Bengkulu Tahun 2014 yang berjumlah 96 orang.

Pengambilan sampel dalam penelitian ini menggunakan metode Accidental Sampling maksudnya yaitu mengambil responden yang kebetulan ada atau tersedia di suatu tempat sesuai dengan konteks penelitian. Dengan kriteria inklusi: pasien rawat jalan dipoliklinik jantung dan penyakit dalam, bersedia menjadi responden, tidak sedang hamil. Data aktifitas fisik dikumpulkan dengan meggunakan kuesioner aktifitas fisik dari World Health Organization (WHO).

Pengolahan data dilakukan dengan berbagai tahapan meliputi editing, pengkodean dan penetapan skor untuk masing-masing kelompok data, kemudian dilakukan entri data lalu dilakukan analisa secara kuantitatif menggunakan komputerisasi program excel, selanjutnya dianalisis dengan menggunakan analisis statistik yaitu untuk menggunakan program komputer SPSS untuk melihat hubungan aktifitas fisik dengan kejadian obesitas sentral. Interpretasi hasil uji: Hipotesis penelitian (Ha) diterima jika nilai $\mathrm{X}^{2}$ $\leq 0,05$ pada taraf kepercayaan $95 \%$.

\section{HASIL}

Tabel 1. Distribusi frekuensi aktifitas fisik dan kejadian obesitas sentral pada pasien poliklinik jantung dan poliklinik penyakit dalam

\begin{tabular}{lcc}
\hline \multicolumn{1}{c}{ Variabel } & Frekuensi & $\begin{array}{c}\text { Persentase } \\
(\%)\end{array}$ \\
\hline $\begin{array}{l}\text { Tingkat Aktifitas } \\
\text { Fisik } \\
\text { Ringan }\end{array}$ & & \\
Tidak Ringan & 64 & 66,7 \\
Obesitas Sentral & 32 & 33,3 \\
Ya & & \\
Tidak & 61 & 63,5 \\
\hline
\end{tabular}

Tabel 1 menunjukkan bahwa lebih dari sebagian responden $(66,7 \%)$ melakukan aktifitas fisik ringan dan menunjukan bahwa lebih dari sebagian responden $(63,5 \%)$ menderita obesitas sentral.

Pada tabel 2 menunjukkan bahwa nilai $\mathrm{P}$ $=0,000<\alpha=0,05$, artinya ada hubungan signifikan antara Aktifitas Fisik dengan Kejadian Obesitas Sentral pada Pasin Poliklinik Jantung dan Poliklinik Penyakit Dalam di RSUD Dr. M. Yunus Bengkulu Tahun 2014.

Tabel 2 Hasil analisis bivariat hubungan Aktifitas Fisik dengan kejadian Obesitas Sentral pada pasien poliklinik jantung dan poliklinik penyakit dalam di RSUD Dr. M. Yunus Bengkulu tahun 2014.

\begin{tabular}{|c|c|c|c|c|c|c|c|c|}
\hline \multirow{3}{*}{$\begin{array}{c}\text { Aktifitas } \\
\text { fisik }\end{array}$} & \multicolumn{4}{|c|}{$\begin{array}{c}\text { Kejadian obesitas } \\
\text { sentral }\end{array}$} & \multirow{2}{*}{\multicolumn{2}{|c|}{ Total }} & \multirow[t]{3}{*}{$X^{2}$} & \multirow{3}{*}{$\begin{array}{c}\mathbf{P} \\
\text { Value }\end{array}$} \\
\hline & \multicolumn{2}{|c|}{$\begin{array}{c}\text { Obesitas } \\
\text { sentral }\end{array}$} & \multicolumn{2}{|c|}{$\begin{array}{c}\text { Tidak } \\
\text { obesitas } \\
\text { sentral }\end{array}$} & & & & \\
\hline & $\mathbf{n}$ & $\%$ & $\mathbf{n}$ & $\%$ & $\mathbf{n}$ & $\%$ & & \\
\hline Ringan & 50 & 78,1 & 14 & 21,9 & 64 & 100 & & \\
\hline $\begin{array}{l}\text { Tidak } \\
\text { Ringan }\end{array}$ & 11 & 34,4 & 21 & 65,6 & 32 & 100 & 15.788 & 0,000 \\
\hline
\end{tabular}

\section{PEMBAHASAN}

Hasil penelitian menunjukan bahwa dari 64 pasien yang mempunyai aktifitas fisik ringan terdapat 50 orang $(78,1 \%)$ mempunyai obesitas sentral. Hasil penelitian juga menyatakan bahwa dari 32 responden yang mempunyai aktifitas fisik tidak ringan terdapat 11 orang $(34,4 \%)$ yang obesitas sentral dengan nilai $p=0,000(\mathrm{p} \leq 0,05)$, sehingga dapat disimpulkan bahwa ada hubungan antara aktifitas fisik dengan kejadian obesitas sentral.

Pada penelitian ini aktifitas fisik mempengaruhi status obesitas sentral pasien poliklinik. Artinya peningkatan asupan makanan jika tidak diimbangi dengan aktifitas fisik yang teratur akan menjadi penumpukan lemak pada jaringan tubuh (abdominal). Hasil penelitian ini juga sesuai dengan penelitian yang dilakukan oleh Shehu (2010), yang mengatakan bahwa penggunaan mobil, air conditioner (didalam mobil, kantor dan rumah) secara substansial meningkatkan gaya hidup dari penduduk perkotaan dan adanya penurunan aktifitas fisik yang menyebabkan gaya hidup sedentari sehingga mengakibatkan obesitas sentral (Rosen, 2010).

Hal ini sebagaimana yang dikemukakan oleh Alam (2007) yang mengatakan bahwa gaya hidup tidak banyak bergerak (sedentary low physical activity) ditambah dengan pola makan buruk yang tinggi lemak dan karbohidrat (fast food) yang tidak diimbangi serat dalam jumlah yang cukup, membuat menum- 
puknya lemak dengan gejala kelebihan berat badan, terutama di bagian perut (Alam, 2007).

Hal ini sejalan dengan penelitian yang dilakukan oleh Elya (2009) mengatakan bahwa Pekerjaan berhubungan dengan perubahan berat badan dan lingkar perut (Obesitas sentral) diduga karena hubungannya dengan aktivitas fisik. Prevalensi obesitas sentral tertinggi pada ibu rumah tangga dan terendah pada petani/nelayan/buruh yang memiliki aktivitas fisik yang lebih tinggi dibandingkan dengan ibu rumah tangga dan pekerja kantor.

World Health Organization (WHO) menyatakan bahwa perubahan dan peningkatan proporsi pekerjaan dalam bidang pelayanan, perkantoran, dan profesi lain cenderung kurang aktivitas fisik jika dibandingkan dengan pekerjaan manual seperti yang terdapat pada masyarakat tradisional. Penurunan aktivitas fisik berhubungan dengan peningkatan kejadian obesitas sentral. Terdapatnya hubungan antara aktifitas fisik berat dengan kejadian obesitas sentral diduga karena efek aktifitas fisik berat melalui penggunaan lemak dari daerah perut, sebagai hasil redistribusi jaringan adiposa (Patrick, 2011).

Hasil penelitian ini juga sejalan dengan penelitian Mustelin (2009) yang menemukan bahwa terdapat hubungan kuat antara aktifitas fisik dan lingkar perut. Aktifitas fisik secara nyata memodifikasi efek dari faktor genetik seseorang. Peningkatan aktifitas fisik lebih berhubungan secara nyata dengan lingkar perut daripada IMT. Satariano (2010) menemukan bahwa lingkar perut menurun secara signifikan dengan lari pada semua umur,

\section{DAFTAR PUSTAKA}

Alam. 2007. Gagal Ginjal, Jakarta: PT. Gramedia Pustaka Utama

Arikunto. 2010. Manajemen Penelitian, Jakarta: Rhinneka Cipta

Arundhana. 2012. Hubungan prilaku gizi seimbang dengan kejadian obesitas sentral pada dosen Universitas Hasanudin Makassar 2012. SI Under Graduate, Universitas Hasanudin

Aru. 2007. Buku Ajar Ilmu Penyakit Dalam. Jakarta: Pusat Penerbitan Departemen Ilmu Panyakit Dalam FKUI namun penurunan yang lebih nyata pada perempuan yang lebih tua daripada yang lebih muda, khususnya pelari jarak pendek (Rosen, 2010).

Beberapa penelitian longitudinal selama 12 tahun menemukan bahwa exercise dapat menurunkan kelebihan berat badan, lemak tubuh total, dan lemak perut. World Health Orgnization (WHO) menyatakan bahwa jumlah energi yang dikeluarkan pada waktu melakukan aktivitas fisik tergantung dari durasi, waktu, dan frekuensi. Aktivitas fisik berat atau sedang minimal 60 menit/hari disarankan untuk menurunkan obesitas (Irwin, 2007).

Penurunan aktivitas fisik berhubungan dengan peningkatan lingkar perut. Rendahnya aktivitas fisik berhubungan positif dengan obesitas sentral. Aktivitas fisik merupakan salah satu faktor yang dapat meningkatkan kebutuhan energi, sehingga apabila aktivitas fisik rendah maka kemungkinan terjadinya obesitas akan meningkat (Soegih, 2009).

\section{KESIMPULAN}

Berdasarkan hasil penelitian dan pembahasan sebagaimana telah diuraikan pada bab sebelumnya, maka dapat disimpulkan bahwa lebih dari sebagian responden melakukan aktifitas fisik ringan, lebih dari sebagian responden menderita obesitas sentral dan ada hubungan antara aktifitas fisik dengan kejadian obesita sentral pada pasien poliklinik jantung dan penyakit dalam RSUD Dr. M. Yunus

Badan Penelitian dan Pengembangan Kesehatan Depkes RI. Riset Kesehatan Dasar 2007. Jakarta : Balitbangkes Depkes RI, 2008

Depkes RI. 2012. Obesitas Sentral. Departemen Kesehatan. Jakarta

Elya. 2009. Faktor resiko Obesitas sentral pada orang Dewasa di Sulawesi Utara, Gorontalo dan DKI Jakarta. Fakultas Ekologi Manusia. Institut Pertanian Bogor.

Gustafsson. 2012. Effect Of Obesity and Overweight On Long Term Mortality In Congestive Heart Failure, Influence Of Left Ventricular Systolic Function. European Heart Journal, (26: 58-64). 
Irwin. 2007. Effect of exercise on total and intraabdominal body fat in postmenopausal women: a randomized controlled trial. JAMA, (3: 323-30).

Mansour. 2007. Cut Off Values for Waist Circumference in rural Iraqi adults for the diagnosis of metabolic syndrome. Rural and Remote Health, (7:765).

Mary. 2007. At a Glance ILMU GIZI, Jakarta: PT. Gelora Aksara Pratama

Mulyono. 2009. Bahaya Obesitas dikutip dari

http://medicastore.com/seminar/94/Bahaya_Obesitas.ht $\mathrm{ml}$ diakses pada tanggal 20 Oktober 2013.

Mustelin. 2009. Trend Peningkatan penyakait degenerative. Jakarta: EGC

Notoatmodjo. 2010. Metodologi Penelitian Kesehatan. Jakarta: Rhineka Cipta

Nursalam. 2008. Metodologi Penelitian Kesehatan Dasar. Jakarta. EGC

Nurul. 2013. Effect Aktifitas Fisik Teratur dengan Kesehatan. Jakarta: Rhineka Cipta

Patrick. 2011. At a glance Medicine, Jakarta: PT. Gelora Aksara Pratama

Pujiati. 2010. Prevalensi dan Faktor Resiko Obesitas Sentral pada penduduk Dewasa Kota dan Kabupaten Indonesia tahun 2007. S2 Post Graduate, Universitas Indonesia

Pusparini. 2007. Obsitas sentral, Sindroma Metabolik dan Diabetes Melitus tipe 2. Universa Medicine, (26: 195-204). Fakultas Kedokteran Universitas Trisakti

Riskesdas. 2007. Riset Kesehatan Dasar (RISKESDAS) 2007. Kementerian Kesehatan Republik Indonesia.
Rosen. 2010. Obesity in the mids of Unyielding food insecurity in developing countries. Amberwaves USDA ERS.

Russel. 2005. Sehat dan Bebas Penyakit dengan Berolahraga. Jakarta: PT Elex Media Komputindo

Saifuddin. 2013. Pengaruh Gaya hidup dengan Obesitas pada Masyarakat Urban. Jakarta: Rhineka Cipta

Satariano. 2010. Resistensi Insulin pada penderita Obesitas Sentral. Jakarta: Gramedia Pustaka Utama

Shehu. 2010. Trend Peningkatan lingkar perut dikalangan dewasa Amerika Serikat. Jakarta: EGC

Soegondo. 2010. Ilmu Penyakit Dalam. Jakarta: EGC

Soegih. 2009. Obesitas, Permasalahan dan Terapi Praktis. Jakarta: EGC

Subardja. 2010. Obesitas primer pada Anak. Bandung: PT. Kiblat Buku Utama

Sudoyo. 2011. Aktifitas fisik teratur untuk kesehatan. Jakarta: Raja Grafindo Persada.

Sukeksi, Andri. 2009. Prevalensi Obesitas dikalangan Dewasa. Jakarta: PT Kiblat Buku Utama

Vague. 2008. Peranan Aktifitas Sedentary dengan Kejadian Obesitas Sentral. Jakarta: EGC

WHO. Obesity : Preventing and Managing the Global Epidemic. Report of a WHO consultation. Geneva, Switzerland : WHO 2012

Wulandari. 2010. Dalam Jurnal Kolom Dampak Obesitas Terhadap Faal Paru. Vol 6. No.9 April 2010, dikutip dari http://www.majalahfarmacia.com/rubrik/one_ news.asp?IDNews=457 Akses tanggal 20 oktober 2013 